\title{
Child labour - An Ugly Face of Travel and Hospitality Industry
}

\author{
${ }^{1}$ Dr. Anupama Sharma, ${ }^{2}$ Ms. Sumita Kukreja, ${ }^{3}$ Dr.Anjana Sharma \\ ${ }^{1,2}$ Asst. Professor Department of Business Administration, Maharaja Surajmal Institute, Janakpuri, Delhi \\ ${ }^{3}$ Asst.Professor Department of Tourism, Govt.P.G. College, Gurgaon, Haryana
}

\begin{abstract}
Tourism industry is one of the world's fastest growing economic sector and largest employer of manpower helps in earning multi-billion dollar annually by attracting a billion of people from one destination to another. But it has a story too. Recent researches reveal that it has various social, economical, cultural, and environmental impacts on society. According to the International Labour Organization's (ILO) Global Report 2006, Tourism affects the lives of 218 million children. India has the distinction of the largest number of working children in the world today. According to Indian official statistics about 13 million children are engaged in tourism industry but unofficial estimates vary between 60-100 million. Throughout India there have been numerous studies which have shown the existence of child exploitation due to tourism. In the year 2006 the tourism and hospitality sector was added to the list of hazardous occupation under the Child Labour Act 1986. As the benefits from tourism industry is increasing day by day and attracting millions of foreign investment, the risk of child labour is increasing exponentially and along with greater demand for human trafficking. Various child labour laws have been enacted to protect the most vulnerable workers from unsafe and unhealthy work environment and to prevent minor children from being forced to work in ways that are considered detrimental to them. The main objective of this paper is to find out the reason why children work in tourism industry, to know the risk involved if they work with tourism sector, and to know the role of government and tourism industry in eradication of this serious problem. This paper also helps in measuring the effectiveness of labour laws and actions taken by the International Labour Organization, World Tourism Organization to mitigate this problem..To evaluate the actual situation of child labour in tourism industry, in this paper information has been gathered through secondary sources like books, magazines (yojna), WTO report, report of Tourism Ministry, News paper etc. For this purpose two research questions were prepared (a) increasing economic benefit of tourism industry is attracting as well as exploiting the future of India. (b) Child Labour laws made to eradicate the problem of child labour has reduced the number of child labourers in papers only not in actual. After analyzing the facts and figures it can be conclude that the problem of child labour and commercial sexual exploitation of children can't be solved easily unless collective efforts have been made by Government officials, NGO's, Civil Society workers and Tourism Industry employers to eradicate it. Policies and legislations should not only formulate but implemented in right spirit. Government and all other institutions must join their hands together to stop all forms of exploitation of children otherwise we will fail to secure the rights of our children who are the future of our India.
\end{abstract}

Key Words:- Tourism, Child-Labour, Labour Law, Hospitality, Sexual-Abuse, Exploitation, Human Trafficking

Definition of key words:

Tourism- According toHunziker \& Krapf (1942)- 'tourism is the totality of the relationship and phenomena arising from the travel and stay of strangers, provided that the stay does not imply the establishment of a permanent residence and is not connected with a remunerated activity.'

Child-Labour-According to ILO (2002) "all children under 15 years of age who are economically active excluding (i) those who are under 5 years old and (ii) those between 12-14 years old who spend less than 14 hours a week on their jobs, unless their activities or occupations are hazardous by nature or circumstances."

Labour-Law - is the body of laws, administrative rulings, and precedents which address the legal rights of, and restrictions on, working people and their organizations.

Hospitality-According to Oxford Dictionary "the friendly and generous reception and entertainment of guests or strangers".

Sexual Assault/ Abuse- " is an assault of a sexual nature on another person, or any sexual act committed without consent. Although sexual assaults most frequently are by a man on a woman, it may involve any combination of two or more men, women and children.

Exploitation-According to Oxford Dictionary “utilize or take advantage of a person for one's own ends.

Human Trafficking - " is the illegal trade of human beings for the purposes of reproductive slavery, commercial sexual exploitation, forced labour, or a worst form of slavery. 
Impact of labour -laws on child Labour: A case of Tourism Industry

\section{Introduction}

Child labour is a fundamental abuse of child rights and a violation of national and international laws. South Asia is known as the home of the largest number of child labourers in the world. This is vindicated by the facts that 30 million of children are working in five large countries of this region.

Working Children, Ages 5 to 14, by Region (in millions)

Table No: 1

\begin{tabular}{|l|c|c|}
\hline \multicolumn{1}{|c|}{ Region } & Total Working & Percentage of children in region \\
\hline Asia & 110.4 & $18.7 \%$ \\
\hline Latin America & 16.5 & $17.0 \%$ \\
\hline North Africa, Middle east & 9.0 & $10.2 \%$ \\
\hline Sub- Sahara Africa & 37.9 & $25.3 \%$ \\
\hline Transitional Countries & 8.3 & $14.6 \%$ \\
\hline Total & 182.1 & $18.5 \%$ \\
\hline
\end{tabular}

According to a UNICEF report on World's Children 2006, India has the largest number of working children and 17 percent of them are under the age of 15 years. About 1.27 crore children, engaged in both hazardous and non- hazardous occupations are working in the BIMARU States (Bihar, Madhya Pradesh,Rajasthan,\&Uttar Pradesh) of India. Over 19 lakh child labour in the 5-14 age group are from the Uttar Pradesh itself. Rajasthan accounts for over 12.6 lakh workers followed by Bihar (over 11 lakh) and Madhya Pradesh (10.6 lakh).Andhra Pradesh with 13.6 lakh child labour stands second in the national list after Uttar Pradesh. Tourism industry is no exception to it.

Tourism industry is one of the world's fastest growing economic sector and largest employer of manpower helps in earning multi-billion dollar annually by attracting a billion of people from one destination to another. This is evident from the fact that international tourist arrivals has doubled from the year 1995 (565.4 million) to the year 2010(1006.4 million). It is expected to reach to 1.56 billion by 2020 , with the largest rate of increase in developing countries including India. It is expected to provide more than 251.6 million jobs by 2020 . According to UN World Tourism Organization, 6-7\% of the world's total jobs directly and millions more indirectly comes through the multiplier effect of this sector.

In India, tourism has made significant contribution to the Indian economy by providing an increase in foreign exchange earnings, creating more employment opportunities and infrastructure development. It is clear from the tourism statistics that international tourist arrival has increased from 5.11 million in 2009 to 5.58 million with a growth rate of $8.1 \%$ in 2010 and foreign exchange earning has increased from US \$11394 million in 2009 to 648.89 billion in 2010. Approximately 705 million domestic tourists have visited different states /UTs of India in 2010. Share of India in world tourist arrival and world tourism receipts is $0.58 \%$ and $1.24 \%$ respectively. It is also expected that tourism demand will grow at an annual growth rate of $8.8 \%$ over the next ten years.

Estimates and Forecasts

Table No 2

\begin{tabular}{|c|c|c|c|c|c|c|}
\hline \multirow[t]{2}{*}{ India } & 2011 & 2011 & 2012 & \multicolumn{3}{|c|}{2022} \\
\hline & INRbn & $\begin{array}{l}\text { \% of } \\
\text { Total }\end{array}$ & Growth & INRbn & $\begin{array}{l}\text { \% of } \\
\text { Total }\end{array}$ & Growth \\
\hline $\begin{array}{l}\text { Direct contribution to } \\
\text { GDP }\end{array}$ & $1,689.8$ & 1.9 & 7.6 & $3,805.2$ & 1.9 & 7.7 \\
\hline $\begin{array}{l}\text { Total contribution to } \\
\text { GDP }\end{array}$ & $5,651.0$ & 6.4 & 7.3 & $12,891.2$ & 6.5 & 7.8 \\
\hline $\begin{array}{l}\text { Direct contribution to } \\
\text { Employment }\end{array}$ & 24,975 & 5.0 & 3.0 & 30,198 & 5.1 & 1.6 \\
\hline $\begin{array}{l}\text { Total contribution to } \\
\text { Employment }\end{array}$ & 39,352 & 7.8 & 2.8 & 47,911 & 8.0 & 1.7 \\
\hline Visitios Exports & 801.4 & 3.8 & 3.5 & $1,382.6$ & 2.0 & 5.2 \\
\hline Domestic Spending & $3,703.1$ & 4.2 & 8.3 & $8,710.3$ & 4.4 & 8.1 \\
\hline Leisure Spending & $3,335.4$ & 3.8 & 8.6 & $7,554.3$ & 3.8 & 7.6 \\
\hline Business Spending & $1,181.3$ & 1.3 & 4.1 & $2,562.2$ & 1.3 & 7.6 \\
\hline Capital Investment & $1,253.9$ & 5.1 & 12.3 & $2,903.9$ & 4.4 & 7.5 \\
\hline
\end{tabular}


The total contribution of Travel \& Tourism includes its wider impacts on the economy. The indirect contribution includes the GDP and jobs supported by Travel \& Tourism investment spending( such as purchase of new aircraft and construction of new hotels), Government collective spending(such as tourism marketing \& promotion, aviation, administration, security services etc.) and Domestic purchases of goods and services by the sectors dealing directly with tourists( including purchases of food and cleaning services by hotels, of fuel and catering services by airlines and IT services by travel agents). The total contribution of Travel and Tourism to GDP was INR5,651.0bn in 2011(6.4\% of GDP) and is expected to grow by $7.3 \%$ to INR $6,062 . .3 \mathrm{bn}(6.5 \%$ of GDP) IN 2012. It is forecast that it will rise by $7.8 \%$ pa to INR12, 891.2bn by $2022(6.5 \%$ of GDP).

Thus Tourism has various social, economical, cultural, psychological and environmental impacts on larger social fabric of society. The facet of these impacts may be positive or negative. On the one hand tourism industry is helping in socio-economic development of India; on the other hand it is degrading the culture, environment and belief system of the society, by giving birth to various social problems like child labour, child trafficking, child pornography, and sexual exploitation of children. Child labour in tourism industry is common in both developing and in developed countries. Children of 14 years or less (and sometimes of 12 years) can be seen as employed in tourism sector working in extremely bad working conditions without even having protection for their long strained working hours under unhealthy and dangerous conditions.

According to ILO (2002) "all children under 15 years of age who are economically active excluding (i) those who are under 5 years old and (ii) those between 12-14 years old who spend less than 14 hours a week on their jobs, unless their activities or occupations are hazardous by nature or circumstances. Added to this are 1517 year old children in the worst forms of child labour." Table- 3 outlines this complex definition dividing into age groups and forms of work that are acceptable and positive, in contrast to unacceptable and negative requiring urgent elimination.

Table :03

\begin{tabular}{|c|c|c|c|c|}
\hline Age Groups & \multicolumn{4}{|c|}{ Forms of Work } \\
\hline & \multicolumn{2}{|l|}{$\begin{array}{l}\text { Non-hazardous work } \\
<43 \mathrm{hrs} / \text { week }\end{array}$} & \multicolumn{2}{|c|}{ Worst forms of child labour } \\
\hline & $\begin{array}{l}\text { Light Work } \\
<14 \mathrm{hrs} / \text { week }\end{array}$ & $\begin{array}{l}\text { Regular Work } \\
>14 \mathrm{hrs} / \text { week } \\
\text { and } \\
<43 \mathrm{hrs} / \text { week }\end{array}$ & $\begin{array}{c}\text { Hazardous Work and } \\
\text { industries } \\
>43 \mathrm{hrs} / \text { week }\end{array}$ & $\begin{array}{l}\text { Unconditional Worst } \\
\text { forms }\end{array}$ \\
\hline & $\begin{array}{l}\text { Does not : } \\
\text { health and development } \\
\text { prejudice } \\
\text { child's attendance at } \\
\text { school and } \\
\text { participation in } \\
\text { vocational training nor } \\
\text { the capacity to benefit } \\
\text { from the instruction } \\
\text { received }\end{array}$ & & $\begin{array}{l}\text { Leads to adverse effects } \\
\text { on child's safety, health } \\
\text { and moral development. } \\
\text { Includes: excessive } \\
\text { workload, physical } \\
\text { conditions of work } \\
\text {,and/or work intensity in } \\
\text { terms of the duration or } \\
\text { hours of work even } \\
\text { where the activity or } \\
\text { occupation is known to } \\
\text { be non-hazardous or } \\
\text { 'safe' } \\
\text { Examples: mining and } \\
\text { construction }\end{array}$ & $\begin{array}{l}\text { Trafficked children, } \\
\text { bonded labour, armed } \\
\text { conflict, prostitution, } \\
\text { pornography and } \\
\text { illicit activities }\end{array}$ \\
\hline $5-11$ & & & & \\
\hline $12-14$ & & & & \\
\hline $15-17$ & & & & \\
\hline
\end{tabular}

NOTE: shaded areas considered as child labour in need of elimination as per ILO Convention No.138 and 182.

Tourism sector by its nature and necessity attracts children to work as labourers. Most of them seen working in hotels, restaurants, and dhabbas as helper, bellboy, and cleaners. Waiters, laundry cleaners, beach boys and girls, rag pickers, tourist guides, kitchen helpers, porters, and coolies. Many children are found selling newspapers, flowers, and other goodies at most historic monuments frequently visited by visitors all over India. India has the distinction of the largest number of working children in the world today. According to Indian official statistics about 13 million children are engaged in tourism industry but unofficial estimates vary between 60-100 million. There are three major issues which affects the future of children directly or indirectly. These are poverty, illiteracy and unemployment or underemployment of their parents. 
Child labour in tourism industry is also direct/indirect result of poor socio-economic conditions of families. In economically weaker sections of society children are considered as a productive resource, who can work on lower cost without complaining. Most of the children working as child labour in India hails from the poorest area like Uttar Pradesh, West Bengal, Bihar and Rajasthan, Chhattisgarh and M.P. Besides poverty, sometimes natural calamities like tsunami, droughts, flood, volcanic eruption, forced migration, armed conflict, displacement, and other crises like political instability, migration, criminal exploitation, discrimination, lack of schools and inadequate social protection etc. leads to the situation of an increase in child labour. Every organization wants to employ children because of their innocence and less troublesome nature and for also they can work on low wages without raising voice against their exploitation.

\section{Review of the Literature:}

According to EQUATIONS Paper for the ILO Karnataka Child Labour Project. State Level Workshop: Role of Employers Associations in Child Labour Elimination on 11th September 2007, at Bangalore- In the tourism sector, millions of children around the country are trapped in a world of work. Many of them are at risk from hazardous and exploitative labour and denied their basic and fundamental right to education, health and childhood. This paper looks at the reasons why children work, the risks to a child working in the tourism sector, the role the tourism industry employers and associations can play to mitigate this problem and the initiatives undertaken by the International Labour Organization, World Tourism Organization (UNWTO) and Government of India to address the problem. Further this paper states that CSR can play an important role in combating child labour by bringing together number of different stakeholders e.g. unions, CSO's, industries and companies around commonly agreed norms through multi-stakeholder approach and to make companies accountable for their impact on society on the basis of agreed international standards like ILO convention.

Professor Nina Rao in her Research Article named Child Labour in the Services in India: The Case of Tourism, presented at the seminar Enslaved Innocence, Child Labour in India, Centre for Jawaharlal Nehru Studies, Jamia Milia Islamia,14 $4^{\text {th }}$ march, 2008 states that Child labor is a complex issue. To start work at between 6-8 years, to learn to deal with hunger, humiliation, physical and sexual abuse, and to go unsung to an early grave is a fate we do not want our children to face .A culture that tolerates poverty, unemployment and illiteracy will also not be vigilant in enforcing any legislation that bans such bitter experiences for lakhs of children who have a right to a better life and a better future. Several NGOs have taken up the task like the MV Foundation in Andhra, Lokadrushti in Orissa, Ganatar in the Rann of Kutch, and Seeds in Karnataka, have all taken the cue from the Census and are seeing the prohibition of child labor as a part of the movement to get the child back to school and propose that the legislation should now be called Child Labor Prohibition and Education Act, 2001.

Ramesh Kanbargi (1991) in his book 'Child Labour in the Indian Sub- Continent' analyses the demographic trends of child labour and its relation with fertility, literacy and education.

Rao's edited work 'Exploited Children' (2000) analyses the dimensions of child labour in india and the broad trends and multidimensional approaches to the problem of child labour. The nature, magnitude, working conditions, causes and consequences are discussed at length. It presents the position of child labour engaged in different industries in different parts of the country. It also reveals and analyses the socio-economic characteristics of child labour, their levels of earning, levels of living and impact on household income. Further, various aspects of migrant child workers are discussed and suggest strategies to eliminate the problem of child labour.

Sanon (1998) in his work 'Worklng Children: A Sociological Analysis' treats the problem more comprehensively. It provides a holistic picture of the problem by narrating qualitative and quantitative aspects of the issue.

Kannan (2001) in his edited work, 'The Economics of Child Labour' discusses the determinants and correlates of child labour in the context of liberalisation and globalisation.

On the initiative of the Ministry of Welfare, Government of India and the UNICEF the Child Labour Cell of National Labour Institute, Noida conducted situational analysis of street children of big metropolitan cities like Madras (Joe, 1992), Uttar Pradesh (Jain et al. 1992), Mumbai (Gosalia et al. 1992), Calcutta (Ghosh, 1992), Kanpur (Pande, 1992), Delhi (Panicker, 1993), Indore (Philip, 1992), Hyderbad (Rao and Malik, 1992). All these studies are based on empirical evidence. Out of these studies reviewed above only a few deals with migrant child labour. No comprehensive empirical study on hoteliering industry has been conducted.

Rajendran (1998) conducted a pilot study on the migrant children working in the hotels and restaurants of Dindigul district of Tamil Nadu reveals the nature of the work and the types of work they are doing. These studies establish the relationship between the eradication of child labour and universalisation of primary education. The studies on child labour reviewed above indicate that the plight of the working children has close relation with certain aspects of individual capitalism. These studies point at the need to understand the prevailing socio-economic situation and advocate a closer look into the deep roots in order to reveal the nature 
of children's economic contribution. Some studies have identified social relations of production and mode of exploitation that conditions the activities of children.

Manavi, an NGO in 1995, show that the lack of awareness in parents and the prevailing illiteracy among the children are the most important factors that compel the poor families to send their children to work It is generally believed that the economic compulsion forces children to seek employment and earn for the family. This has been proved by different studies such as those of Musafar Singh (1980). Ghosh (1984), Sinha (1991), Singh (1992), Kanbargi (1991), and Rao (1999). These studies give multiple reasons for children being in labour market.

Weiner (1991), in his study named 'Child and State in India', presents an academic discussion on the various aspects of' child labour and a critical perspective towards the educational policies of the Government of india and that of the states. He stressed the need for putting compulsory education on the political agenda. His works brings out the historical linkages of child labour with the age-old value system based on caste system. Weiner holds the view that rather than the low per capita income and the less developed nature of the economy, the belief' system of the Indian society and the elite is largely responsible for the perpetuation of child labour in the country. He also critically analyses the education policy pursued by the state and central governments and points out its elitist character.

Hinvay (1991), in his study, 'Eradicating Child Labour from the World: Some Basic Issues' clearly elaborates the true nature and magnitude of the problem of child labour in lndia with extensive demographic and statistical data.

Burra's , (1995), in his investigation study named 'Born to Work', which is based on first hand field investigations carried out in the brassware, gem polishing, pottery industry, lock making and glass factories, have described the different working conditions of child labourers. It emerges that a large number of children as young as five or six years work throughout the night under great health and safety hazards. Burra argued that the state policies aimed at protecting children are poorly conceived and badly enforced. This study provides hard evidence of widespread abuse and exploitation.

'Human Rights and Child Labour in Indlan Industries' by Saksena (1999), analyses the factors responsible for the prevalence of child labour and the consequences and repercussions of sending children to work. This study also analyses the steps taken by the Government of India since independence, and points out the loopholes of legislation, policies and programmes.

On the initiative of the Ministry of Welfare, Government of India and the UNICEF the Child Labour Cell of National Labour Institute, Noida conducted situational analysis of street children of big metropolitan cities like Madras (Joe,1992), Utter Pradesh (Jain et al. 1992), Mumbai (Gosalia et al. 1992), Calcutta (Ghosh, 1992), Kanpur (Pande, 1992), Delhi (Panicker, 1993), Indore (Philip, 1992), Hyderbad (Rao and Malik, 1992). All these studies are based on empirical evidence. . These studies establish the relationship between the eradication of child labour and universalisation of primary education.

The studies on child labour reviewed above indicate that the plight of the working children has close relation with certain aspects of individual capitalism. As the million of children are working in the tourism industry and facing lots of social problems like loosing their social identity, human trafficking, child prostitution and various kinds of human disease, a need arise to investigate the reasons, adverse effects and seriousness of this social problem. This paper helps in highlighting the reasons why children work,the risk to a child working in the tourism sector, the role the tourism industry employers and associations can play to mitigate this problem and further this paper helps in identifying the the impact of labour laws and initiatives undertaken by the International Labour Organization, World Tourism Organization and Government of India to address the problem.

\section{Objectives :}

a) To know the reasons why are children attracted towards tourism industry to work

b) To find out the adverse effect of working for long hours in different sectors of tourism industry.

c) To evaluate the effectiveness of various labour laws and actions initiated by Government, The Ministry of Women and Child Development, and United Nations World Tourism Organization.

\section{Reasearch Questions:}

(a) Increasing economic benefit of tourism industry is attracting as well as exploiting the future of india.

(b) Labour laws made to eradicate the problem of child labour has reduced the number of child labourers in papers only but not in actual.

\section{Methodology:}

Research methodology is partly descriptive, partly exploratory and partly casual .For this study data and information has been collected with the help of Books, Magazines, Newspapers, Research Articles, 
Research Journals, E-Journals, UNWTO Report, Report of Ministry of Tourism, and Report of Ministry of Women and Child Development etc.

\section{Impact of Child Labour on Society}

Child labour and society are complex phenomenon and to some extent both are interrelated too. The existence of child labour has an adverse impact on society . It is not only changing the structure of society but also damaging its future democratic development .Some Social Impacts of Child Labour are as follows:-

1-Children engaged in tourism sector are very much inclined to imitate the foreign tourist. They themselves have experienced changes in their habits and outer appearances. Regular contact with foreign tourist is getting children away from their own culture and making them more interested in luxurious goods.

2- Children working in Tourism Industry are suffering from the problem of Social isolation. Due to extended hours of work, children do not have time for playing with their peers. In many occupations, such as beach working, house attendants or maids, children are working on their own, separated from their families and children of their age.

3-Further they are facing the problem of family -disorganization. Sometimes they have to rear their own brother and sister as their parents have gone out of place to earn money or have left them alone to die. In this situation sometimes children have to move away from their family as they are unable to find work nearby. This situation leaves families with their members spread apart. The family itself cannot act as a unit anymore. It fails to provide for a place where children can relax and feel safe.

4-Children being brought up under such circumstances may not be able or motivated to care for their own children in a different way. They are unable to provide them a safe upbringing or childhood. Which results in disorganized personalities in later adulthood.

Though tourism is not the direct cause of sexual exploitation, but it provides easy access to it. Child sex tourism is one of the most abhorrent types of child labour .It involves the commercial sexual exploitation of children by men or women who travel from one place to another and of those who are in contact with strangers. Generally Nepali and Indian girls from rural areas are trafficked for commercial sexual exploitation in major urban centers such as Mumbai, Calcutta, and New Delhi. Children of north-eastern states are more vulnerable to trafficking. According to world vision approximately 2 million children are the victims of global commercial sex trade. Many of these children are either sold into prostitution to pay off family debts or some of them are forcibly recruited on the street for begging or to work in other commercial centers. Children involved in tourism related services run the risk of being sexually exploited and are highly vulnerable to contract HIV/AIDS as they come in contact with both locals as well as tourist. Sometimes poor working conditions like long working hours, unstable employment, and low pay etc affects the health of small children and sometimes results in ending their life.

\section{Impact on children}

\begin{tabular}{|c|c|c|}
\hline Physical & Moral & Psychological \\
\hline $\begin{array}{l}\text { - fatigue from long } \\
\text { working hours } \\
\text { - physical harm } \\
\text { (violence, chemicals, } \\
\text { abrasions hazards } \\
\text { associated with the } \\
\text { work) } \\
\text { - HIV-AIDS, other } \\
\text { sexually transmitted } \\
\text { diseases } \\
\text { - impaired growth }\end{array}$ & $\begin{array}{l}\text { - exposed to drugs, } \\
\text { sex, violence } \\
\text { - exposed to adult } \\
\text { behaviours } \\
\text { - lack of schooling } \\
\text { - too much } \\
\text { independence? }\end{array}$ & $\begin{array}{l}\text { - low self esteem } \\
\text { - marginalized } \\
\text { from society } \\
\text { - stigmatized } \\
\text { - lonely } \\
\text { - loss of a safe } \\
\text { upbringing/ } \\
\text { childhood } \\
\text {-stress } \\
\text { - lack of chance } \\
\text { to develop } \\
\text { cognitive skills }\end{array}$ \\
\hline
\end{tabular}

\section{Impact of labour laws on Child Labour}

Child labour is a serious issue for the developing countries like India. Government of India has enacted various laws and has taken serious initiatives to eliminate this problem. Child labour laws were enacted to protect the most vulnerable workers from unsafe and unhealthy work and work environment. Child labour laws state that children under the age of 14 cannot hold jobs. Considering the magnitude and extent of this problem Government of India has formed the first committee called Gurupadswamy committee to study the issue of child labour and to suggest measures to tackle it. This committee has ovserved that as long as the problem of poverty will continued, it would be difficult to eliminate child labour totally. Further this committee has recommended to adopt the multiple policy approach to deal with the problems of working children.

Pursuant to this in 1974 Government of India has developed a scheme called Integrated child development service scheme for physical, psychological,and emotional development of children and to reduce the rate of mortality,morbidity,malnutrition and school dropouts.

To protect the children from long strained working hours and unhealthy work environment in the year 1986, an act named Child Labour Prohibition and Regulation Act was amended by the government. This Act describes a child labour as a person who has not completed his/ her 14 year of age and doing labour works. 
Impact of labour -laws on child Labour: A case of Tourism Industry

Further this act aims to normalize the working hours and the conditions of child labourers and to protect them from the hazardous working conditions. As to assess the success of this act it is vindicated by the fact that till now only 22,092 people were prosecuted for violating the law, out of which 3,049 people were convicted whereas only 12 persons were sent to jail. During 2007-09 under CLPRA only 7 prosecution and 4 convictions has been done in order to rescue child domestic workers and to punish their employers. Thus it can be said that nothing has been done in the name of effective implementation of Child Labour Prohibition and Regulation Act.

.Further this act failed to provide formal compulsory education to the children. According to Government of India around 90 million of 179 million children in the 6-14 age group do not go to school and are engaged in some occupation or other. Still $50 \%$ of children are deprived of their right to a free and happy childhood. Seeing this worst situation of children the government felt a need for the introduction of Right to Education Act to provide the compulsory elementary education to the children. As a result on April It 2009 , Right to Education Act came into existence.

In consonance with the above approach, a National Policy on Child Labour was formulated in 1987 to adopt a gradual \& sequential approach with a focus on rehabilitation of children working in hazardous occupations. At present the scheme is operational in 266 districts in 20 States and covering around 3.39 lakh children through 7, 300 special schools. Under this scheme, children withdrawn from work are admitted into special schools where they are provided bridge education, vocational training, stipend of Rs.150, mid day meals, health care and so on.

To facilitate eradication of child labour the Ministry of Labour and Employment has launched a National Child Labour Project (NCLP) Scheme in 9 districts of the country, to provide formal/non-formal education along with vocational training, a stipend of Rs. 100 per month, supplementary nutrition and regular health checkups so as to prepare them to join regular mainstream schools. Under the Scheme, funds are given to the District Collectors for running special schools for child labour. Most of these schools are run by the NGOs in the district. Yet now under this scheme 150 child labour projects have been sanctioned for rehabilitating children in most endemic areas and 1.5 lakh children have already been mainstreamed in the special schools.

Government of India is trying to converge schemes of different Ministries, such as Human Resource Development, Women and Child Development and Urban Housing and Rural Poverty Alleviation to help working children and their families reap the benefits of Government schemes and as well as releasing $75 \%$ of the project cost under Grant-In- Aid scheme to non-governmental organizations in districts not covered under National Child Labour Project (NCLP) Scheme .The labour Ministry is also implementing a Pilot Project Converging against Child Labour in collaboration with the International Labour Organization to prevent trafficking and migration of child labour.

The Government of India has also adopted the National Charter for Children which was notified in the gazette of India on $9^{\text {th }}$ February,2004 to protect the children's right to survival, health and nutrition, early childhood care, education,, life and liverty,freedom of expression ,freedom of association, the right to a family and the right to be protected from economic exploitation and all forms of abuse.

Ministry of Women and Child Development has prepared a National Plan of Action for Children 2005.This Plan includes goals, objectives, strategies, and activities for improving nutritional status of children, reducing Infant Mortality Rate and MMR, increasing enrolment ratio and reducing dropout rates, universalisation of primary education, and increasing coverage of immunization.

Government and State Governments are taking proactive measures through strict enforcement of legislative provisions to tackle the problem of child labour and are conducting regular inspections and raids to detect cases of violations. From the following table it is clear that various inspections and actions have been taken by different Sates of India to eradicate the problem of child labour but failed to avoid the violation of law.

Table:4

\begin{tabular}{|c|c|c|c|}
\hline State & Inspections & Violations & Action Taken \\
\hline Bihar & 183 & 113 & 20 \\
\hline Chandigarh & 71 & 0 & 0 \\
\hline Delhi & 127 & 26 & 0 \\
\hline Goa & 2000 & 2 & 0 \\
\hline Gujarat & 10389 & 2 & 6 \\
\hline Harayana & 434 & 6 & 19 \\
\hline Karnataka & 6491 & 316 & 1 \\
\hline Kerala & 4479 & 12 & 0 \\
\hline Orrisa & 154 & 200 & 23 \\
\hline Rajasthan & 371 & 14 & \\
\hline Punjab & 1148 & 162 & \\
\hline
\end{tabular}


Impact of labour -laws on child Labour: A case of Tourism Industry

\begin{tabular}{|c|c|c|c|}
\hline Tamil Nadu & 1,683 & 20 & 2 \\
\hline Tripura & 336 & 4 & 0 \\
\hline Uttar Pradesh & 1,669 & 556 & 0 \\
\hline West Bengal & 983 & 15 & 0 \\
\hline
\end{tabular}

Hindustan Times, Oct.10,2007,Pg.10 based on RTI applications by Bal Adhikar Abhiyan)

Since poverty is the root cause of this problem, the Government has been laying a lot of emphasis on the rehabilitation of these children and on improving the economic conditions of their families. As a result the coverage of the NCLP has been increased from 100 districts in $9^{\text {th }}$ Plan to 250 districts during the $10^{\text {th }}$ Plan. The government of India recently announced a ban on the employment of children as domestic servants and workers in roadside eateries, restaurants, hotels, and shops etc. to save them from physical violence, psychological trauma and sexual abuse. With the ban coming into force, child labour in tourism industry is now categorized as hazardous work under the child labour act.

In the name of effective implementation of the ban, children are picked up from the streets, roadside eateries and hotels and put in rehabilitation and juvenile homes not protected from sexual abuse and exploitation. Thus this ban does nothing to eliminate child labour. This ban is being seen as a tool by the government to curb the menace of child labour but does not address the issue behind the problem. Though measures have been underway by to eliminate the poverty which is the major cause of child lobour but actual rehabilitation can't take place unless or until the poverty and thereby the means of livelihood for the family are not thought about and taken care of.

Apart from this ban earlier various other acts has been introduced by union government and state government to protect the child from exploitation and child labour. Laws pertaining to child labour are as follows:-

- Children [Pledging of Labour] Act (1933)

- Employment of Children Act (1938)

- The Bombay Shop and Establishments Act (1948)

- Child Labour -Prohibition and Regulation Act

- The Indian Factories Act (1948)

- Plantations Labour Act (1951)

- The Mines Act (1952)

- Merchant Shipping Act (1958)

- The Apprentice Act (1961)

- The Motor Transport Workers Act (1961)

- The Atomic Energy Act (1962)

- Bidi and Cigar Workers (Condition of Employment) Act (1966)

- State Shops and Establishments Act

Thus Government of India has taken major initiatives to eradicate the child labour by passing special legislations and punishing the offenders. Not only government authorities but also other social organizations , trade unions, entrepreneurs and several other non-government organizations are playing an important role in rescuing the child labour at the central and state lavel.Inspite of all these efforts the problem of child labour is still prevailing in the society.Though the no. of child labourers have reduced to some extent. According to National Sample Survey organization Report in 2009-10,the number of working children in the age group of 514 years has dipped to 49.84 lakh from 1.26 crore in 2001.It has seen that the number of child labourer in the age group of 5-14 years has declined by $10 \%$ and number of children in hazardous work has declined by $30 \%$.

Projects implemented in various states of the country adopt an essentially holistic approach, combining strategies aimed not only to the withdrawal of children from work, but also to enhance communities' awareness, ownership and collective action for the protection and promotion of children rights. Existing strategies include: a) Promotion of education as both, key preventive measure and essential component for the rehabilitation of released children; b) Addressing poverty related factors through the promotion of self-help-groups; c) Advocacy and social mobilization for the elimination of child labour.

In Uttar Pradesh, for instance, this strategy led to an increase of more than 47 per cent in school enrolment and attendance among the villages targeted by the ongoing UNICEF child labour elimination intervention. Self-Help-Groups/NREGP has been playing a crucial role in reducing indebtedness among poor rural families. But still it requires much more to done to address the problem of child labour.

Thus Child labour is a serious issue. It is the responsibility of government, non-government organizations, social welfare societies, media and other civil societies to take necessary recourse or legal actions to eradicate it. National and International tourism organizations, can also play an effective role in eliminating this problem. It is true that this serious problem can't be removed in short run but efforts can be made to reduce 
Impact of labour -laws on child Labour: A case of Tourism Industry

the intensity of child labour. Some preventive measures like providing free health care, free education, free meal, less working hours and provision of rehabilitation centers etc can be helpful in reducing the seriousness of this problem.

\section{Initiatives to Combat Child Labour in Tourism Sector from United Nation World Tourism Organization: \\ UNWTO established a Task Force in the year 1997 to Protect Children from Sexual Exploitation in Tourism.} This is a global action platform of tourism-related key-players from the government and the tourism industry sectors, international organizations and non-governmental organizations (NGOs), and media associations whose aim is to prevent, uncover, isolate and eradicate the sexual exploitation of children in tourism. In the year, 2001 The Global Code of Ethics for Tourism (GCET) was adopted with a comprehensive set of principles which outlines to guide tourism development and to serve as a frame of reference for the different stakeholders in the tourism sector, with the objective of minimizing the negative impact of tourism. In the preamble of the global code of ethics, they have very clearly agreed and referred to the conventions and recommendations adopted by the International Labour Organization (ILO) in the area of prohibition of forced labour and child labour. The only mandate of the task force was to look into protection of children from sexual exploitation, but in the year 2007 they agreed to rewrite the objectives of this Task Force to make clear that the sexual abuse would remain the main focus, but with a broader view to include other aspects that could lead to sexual abuse such as child labour. The reason to broaden the scope of the task force was because they acknowledge that the children working in tourist areas were often invisible and mostly behind the scenes is hazardous to the child and leading to sexual abuse.

\section{Measures initiated by International Labour Organisation to eradicate child labour}

Concerning the seriousness of child labour in the year 2010, the international community adopted a roadmap for achieving the elimination of the worst forms of child labour by 2016, which stressed that child labour is an obstacle to children's rights and a barrier to development. In this conference the role of enterprises, corporate and trade unions has been recognized to tackle the problem of child labour. Further in this conference a need for ratification in existing conventions and laws has been identified by ILO in order to eradicate this serious problem.

This year is going to be organized as" world Day against child labour 2012" to tackle the child labour. International Labour Organization has made a call to all other associated countries to stand together to remove all anomalies occurred in the way of elimination of this serious problem.

There is near universal ratification of the UN Convention on the Rights of the Child. The Convention states that children have the right to be protected from performing any work that is likely to be hazardous or to interfere with the child's education, or to be harmful to the child's health or physical, mental, spiritual, moral or social development. It also states that primary education should be compulsory and available free to all and encourages the development of different forms of secondary education available and accessible to every child. The United Nations General Assembly has also adopted two Optional Protocols to the Convention to increase the protection of children from involvement in armed conflicts and from sexual exploitation.

The ILO Worst Forms of Child Labour Convention,1999(No.182) calls for "immediate and effective measures to secure the prohibition of the worst forms of child labour as a matter of urgency". The worst forms are defined as:all forms of slavery, or practices similar to slavery, such as the sale and trafficking of children, debt bondage and serfdom, as well as forced labour, including forced or compulsory labour, including forced or compulsory recruitment of children

ILO has called for "re-energized" global campaign to eliminate the worst forms of child labour. In its Global Report on child labour, the ILO has said that the global number of child labourers had declined from 222 million to 215 million, or 3 per cent, over the period 2004 to 2008 , representing a "slowing down of the global pace of reduction." The report also expressed concern that the global economic crisis could "further brake" progress toward the goal of eliminating the worst forms of child labour by 2016. To eradicate this menace a multi-dimensional approach consisting of awareness building and consciousness rising, community participation, alternative and viable social economic rehabilitation and enforcement of national and international legal instruments in relation to children and other similar plans are needed for linking the elimination of child labour.

\section{Conclusion}

Child labour is a serious social problem. It is clear that the problem of child labour and commercial sexual exploitation of children can't be solved easily unless collective efforts have been made by Government officials, NGO's, Civil Society workers and Tourism Industry employers to eradicate it. Policies and legislations should not only formulate but implemented in right spirit. Government and all other institutions must join their hands together to stop all forms of exploitation of children otherwise we will fail to secure the rights of our children who are the future of our India. 
Impact of labour -laws on child Labour: A case of Tourism Industry

The Government is committed to eliminate child labour in all its forms and is moving in this direction in a targeted manner. It was unanimously recognized therein that the problem of child labour, being inextricably linked with poverty and illiteracy, cannot be solved by legislation alone, and that a holistic, multipronged and concerted effort to tackle this problem will bring in the desired results.

\section{Recommendations:}

* Different sectors and sections in tourism such as unorganized sector, business development sector and industry must formulate a code - "Child Labor free Tourism"

* Tourism Industry must follow the minimum age provisions in accordance to National labour laws and Regulations.

* They must develop their own codes of conduct and must make it explicit in their company's formal policy that all forms of child labour will be avoided, and they will adopt a "No Child Labour Policy".

* The employers and their organization can form their employer's federations to influence the development of national policies on child labour.

* Must Create awareness among tourism personnel on the rights of the child and how to stop child labour.

- Must participate in efforts to combat child labour in industries through multi-stakeholder initiatives collaborative efforts of industries, companies, trade unions, NGO's, Government etc.

* Working with NGO's by assisting the children to go back to school etc.

* ensure that all the child's needs are catered for by the parents or guardians

* ensure that no child under 18 years of age is employed, be it temporary or permanent

* prosecute in the court of law employers who illegally employ minors

* ensure that all employees are well paid to cater for their family needs

* incorporate chefs, local leaders, teachers and parents and interested persons and educate the community on the side effects of child labour

* inspect labour officers and union leaders in order to curb bribery and/or corruption by employers of child workers

[1] Child Labour: An Ugly Face Of Tourism, Equations, September 2007.

[2] Tourism and Labour:Opening vistas and Emerging Challenges,Equations, December 2008.

[3] "Talk For Change For Making Tourism Sustainable,Equitable And Just”,Regional Consultation On Responsible Tourism In The North Eastern States Of India,Dated:26-27 August 2010,Gangtok Sikkim,Organized by: Impulse NGO Network \& Equations.

[4] United States Department Of Labor,2007 Findings on the Worst Forms Of Child Labor-India,27August2008,available at: http:www.unhcr.org/refworld/docid/48caa4763d.html[accessed 12 june 2011].

[5] Susan Bliss,NSW Manager Global Education,Lecturer-University of Sydeny and Macquarie University,President- Geography Teachers'Association of New South Wales,Director- Australian Geography Teachers'Association ,"Child Labour In Tourism Industry:Social Justice and Human Rights".

[6] World Tourism Organisation (WTO)http://www.world-tourism.org/market_research/facts/market_trends.htm

[7] Prof. Nina Rao's: Child Labour in the services in India: The Case of Tourism,( Revised version of the paper presented at the Seminar Enslaved Innocence, Child Labour in India, Centre for Jawaharlal Nehru Studies, Jamia Milia Islamia,14 March,2008.

[8] Notification banning child labour in Domestic and Hospitality Sector effective from 10 October,2006.

[9] BBC news online,Thursday,22 June,2000,10:13 GMT 11:13 UK- Tourism Industry is the largest employer of children by Sushil Sharma in Kathmandu.

[10] Narayan,A. (1988). Child Labour Policies and Programmes:The Indian Experience. In combating child labour,edited by A. Bequele and J. Boyden.Geneva: ILO.

[11] Ministry of Labour and Employment, Annual Report of the Ministry of Labour 2006-07,para 12.3.

[12] U.S. Department of State," Country Reports-2007: India," section 5.

[13] Government of India, Child Labour- Prohibition and Regulation Act, articles 7,8,14.

[14] Ministry of Women and Child Development,Initiatives taken by Ministry of Women and Child Development to Combat Trafficking of Women and Children, New Delhi,Oct.11,2006,para I,available from http://wcd.nic.in/INITITrafficking.doc.

[15] U.S. Embassy- New Delhi,reporting,December 4,2007 and March 20, 2008.etc.

[16] Bureau of Immigration,Govt.of India,for 1997-2008.

[17] Ministry of Tourism,Govt. of India,for 2009\& 2010.

[18] UNWTO Tourism Market Trends 2007 Edition, for the years upto 2005.

[19] UNWTO Barometer June 2009 for 2006 \&2007 and Barometer June 2010 for 2008 \&2009.

[20] Yojna, May 2008, Vol.52,pg.14,\& 29,ISSN-0971-8400.

[21] Yojna, November 2008, Vol.52,pg.47,\& 48, ISSN-0971-8397.

[22] Maillu, D.G. Our Kind of Polygamy. Heinemann: Nairobi. 1988

[23] UNDP. Human Development Report 1999. Oxford Univ. Press: New York. 1999. (p. 237, Table 27. Gender Gaps in Burden and Time Allocation)

[24] Institute of Economic Affairs. Our Problems Our Solutions: An Economic and Public Policy Agenda. Ministry of Education: Nairobi. July 1998.

[25] UNDP. Human Development Report 1999. Oxford University Press: New York. 1999. (p.178, table 10).

[26] Ministry of Education and Human Resource Development: Republic of Kenya. Results of the 1995 Primary School Consensus. Government of Kenya: Nairobi. 1998. (p.14 and 15, figure 5)

[27] UNICEF. The State of the World's Children 1999: Education. UNICEF: Paris. 1999. (p.107 table 4)

[28] Ministry of Education and Human Resource Development: Republic of Kenya. Results of the 1995 Primary School Consensus.

[29] Government of Kenya: Nairobi. 1998. (p.20, figure 8.: Source International Research Network Ltd.) 